\title{
Left ventricular aneurysm complicating apical hypertrophic cardiomyopathy
}

\author{
Liam Toner (ㄷ, , Anoop Koshy, ${ }^{1,2}$ Omar Farouque, ${ }^{1,2}$ John Cotroneo ${ }^{1}$
}

${ }^{1}$ Department of Cardiology, Austin Health, Melbourne, Victoria, Australia

${ }^{2}$ The University of Melbourne, Melbourne, Victoria, Australia

\section{Correspondence to}

Dr Liam Toner;

liammtoner@gmail.com

Accepted 10 September 2020

\section{DESCRIPTION}

A 44-year-old previously well man presented to our emergency department with exertional chest pain. An ECG showed widespread deep T-wave inversion and left ventricular hypertrophy by voltage criteria, figure 1 . High-sensitivity troponin I was persistently elevated at $48-58 \mathrm{ng} / \mathrm{L}$ (normal $<20 \mathrm{ng} / \mathrm{L}$ ) and he was managed as a non-ST elevation acute coronary syndrome.

Coronary angiography demonstrated patent coronary arteries with mild luminal irregularities. Left ventriculography demonstrated a 'spade-like' left ventricular cavity in diastole and systole and a large apical aneurysm, figure 2 and video 1 . Invasive pressure measurements demonstrated a peakto-peak midventricular systolic gradient of $141 \mathrm{~mm}$ $\mathrm{Hg}(284 / 15 \mathrm{~mm} \mathrm{Hg}$ in the aneurysmal apex and $143 / 18 \mathrm{~mm} \mathrm{Hg}$ in the left ventricular base).

A transthoracic contrast echocardiogram demonstrated a large apical aneurysm, with left ventricular hypertrophy extending from mid to distal left ventricular segments, with midventricular cavity obliteration in systole. There was reduced contrast enhancement in the thinned apical myocardium, indicating reduced perfusion, figure 3 and video 2 .

'A diagnosis of apical hypertrophic cardiomyopathy (HCM, Yamaguchi syndrome) complicated by a large left ventricular aneurysm was made. The

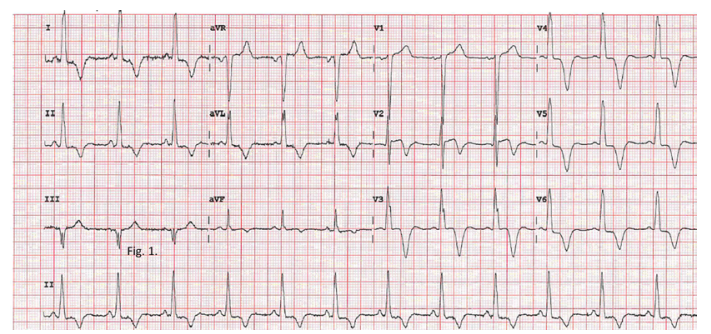

Figure 1 ECG showing widespread T-wave inversion and left ventricular hypertrophy by voltage criteria.
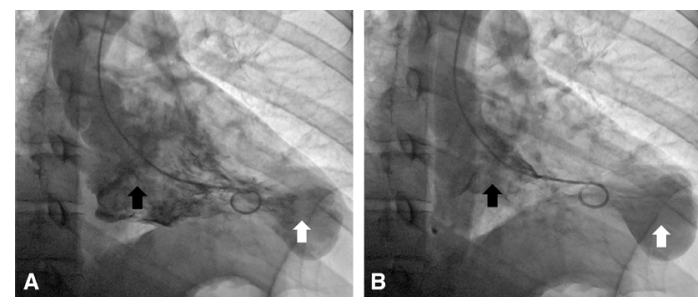

Figure 2 Left ventriculography demonstrating a 'spadelike' left ventricular cavity (black arrow) and a large apical aneurysm (white arrow) in diastole (figure 2A) and systole (figure 2B). See video 1.

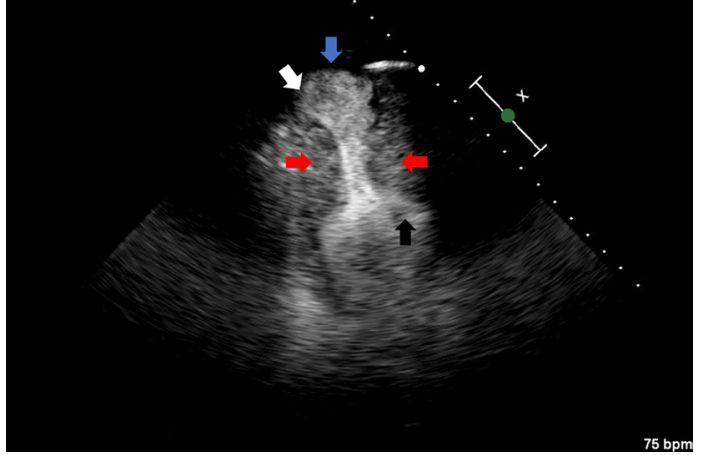

Figure 3 A transthoracic contrast echocardiogram demonstrating a large apical aneurysm (white arrow), with left ventricular hypertrophy extending from mid to distal left ventricular segments (red arrows), with midventricular cavity obliteration in systole. There was reduced contrast enhancement in the thinned apical myocardium (blue arrow). See video 2.

patient was commenced on a beta-blocker. The patient's clinical presentation was attributed to demand ischaemia and small vessel angina. Given the incidental mild irregularities demonstrated on coronary angiography the patient was also commenced on a statin and aspirin'.

HCM is a spectrum of disease encompassing primary left ventricular hypertrophy of several morphologic subtypes. The genetic basis of the disorder involves sarcomeric protein mutations. ${ }^{1}$ The clinical features include heart failure,

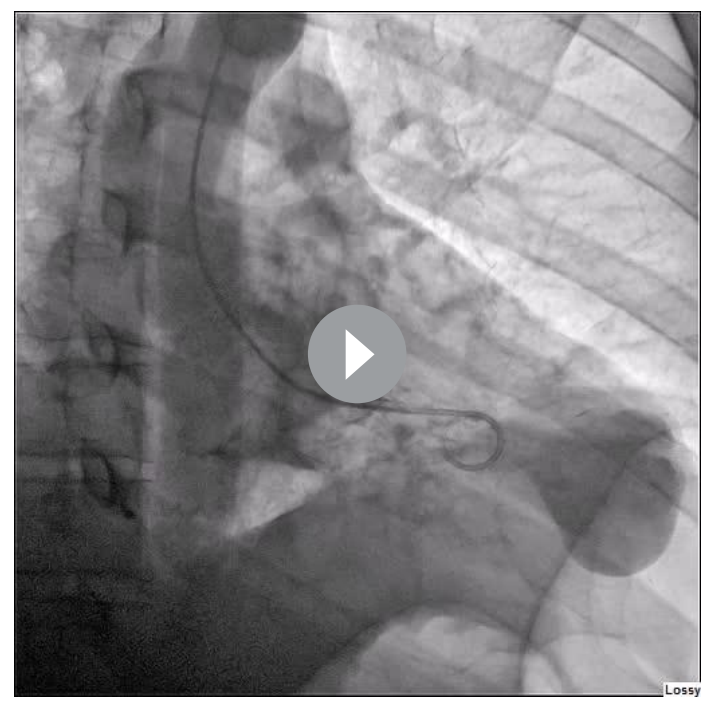

Video 1. Left ventriculography demonstrating a 'spadelike' left ventricular cavity a large apical aneurysm 


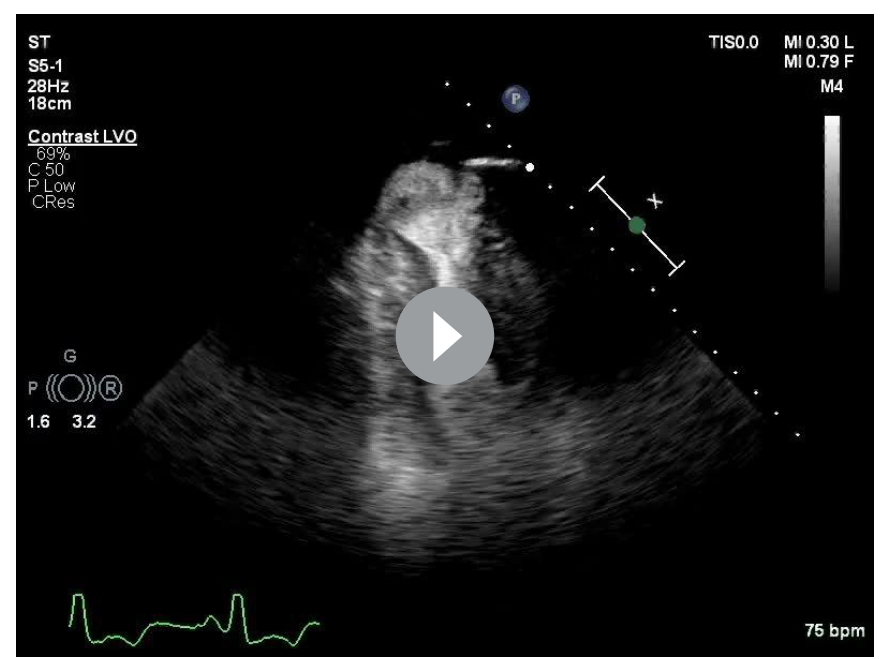

Video 2 A transthoracic contrast echocardiogram demonstrating a large apical aneurysm with left ventricular hypertrophy extending from mid to distal left ventricular segments, with mid ventricular cavity obliteration in systole

ischaemic chest pain, arrhythmia and pulmonary hypertension. The apical subset is often defined as left ventricular predominating at the apex with a wall thickness $\geq 15 \mathrm{~mm}$ and a ratio of maximal apical to posterior wall thickness of $\geq 1.5$ detected on echocardiography or cardiac MRI. ${ }^{2}$ The apical left ventricular hypertrophy may cause large midventricular pressure gradients, confers an elevated risk of atrial fibrillation and is less associated with left ventricular outflow tract obstruction. ${ }^{2}$ Apical HCM may be further complicated by aneurysm formation resulting in increased risk of thromboembolism, ventricular arrhythmia and sudden cardiac death. ${ }^{3}$ Patients suspected of HCM may be further investigated with cardiac MRI to assess the distribution and severity of left ventricular hypertrophy or aneurysm in a more sensitive manner compared with echocardiography. In addition, cardiac MRI may demonstrate the presence and distribution myocardial fibrosis which is of diagnostic and prognostic importance. $^{2}$

\section{Learning points}

Patients with hypertrophic cardiomyopathy may present with exertional chest pain.

- Apical hypertrophic cardiomyopathy may be complicated by left ventricular aneurysm formation.

- Such aneurysms confer an increased risk of thromboembolism, ventricular arrhythmia and sudden cardiac death.

Contributors All authors have read and approved the final manuscript. All authors have been involved directly in the patients care. Manuscript writing was done by LT. Manuscript editing was performed by AK, OF and JC.

Funding The authors have not declared a specific grant for this research from any funding agency in the public, commercial or not-for-profit sectors.

Competing interests None declared.

Patient consent for publication Obtained.

Provenance and peer review Not commissioned; externally peer reviewed.

\section{ORCID iD}

Liam Toner http://orcid.org/0000-0002-7288-3362

\section{REFERENCES}

1 Elliott PM, Anastasakis A, et al, Authors/Task Force members. 2014 ESC guidelines on diagnosis and management of hypertrophic cardiomyopathy: the task force for the diagnosis and management of hypertrophic cardiomyopathy of the European Society of cardiology (ESC). Eur Heart J 2014;35:2733-79.

2 Hughes RK, Knott KD, Malcolmson J, et al. Apical hypertrophic cardiomyopathy: the variant less known. J Am Heart Assoc 2020;9:e015294.

3 Rowin EJ, Maron BJ, Haas TS, et al. Hypertrophic Cardiomyopathy With Left Ventricular Apical Aneurysm: Implications for Risk Stratification and Management. J Am Coll Cardiol 2017;69:761-73.

Copyright 2020 BMJ Publishing Group. All rights reserved. For permission to reuse any of this content visit

https://www.bmj.com/company/products-services/rights-and-licensing/permissions/

BMJ Case Report Fellows may re-use this article for personal use and teaching without any further permission.

Become a Fellow of BMJ Case Reports today and you can:

- Submit as many cases as you like

- Enjoy fast sympathetic peer review and rapid publication of accepted articles

- Access all the published articles

- Re-use any of the published material for personal use and teaching without further permission

\section{Customer Service}

If you have any further queries about your subscription, please contact our customer services team on +44 (0) 2071111105 or via email at support@bmj.com.

Visit casereports.bmj.com for more articles like this and to become a Fellow 